\title{
Discussion: The engineering properties of Victorian structural wrought iron
}

S. S. J. Moy BSc, PhD, CEng, FICE

Visiting Professor, School of Civil Engineering and the Environment, University of Southampton, UK

H. W. J. Clarke BEng, PhD

Ramboll Whitby Bird, Winchester, UK, formerly School of Civil Engineering
S. R. Bright BEng, PhD, CEng, MICE

Principal Engineer, Cass Hayward LLP, Consulting Engineers, Chepstow, UK M. Bussell BSC

Retired consultant, affiliate member of ICE

\section{Contribution by M. Bussell}

There is a large stock of wrought iron structures, many of historic interest, and so considerations of economy, sustainability and heritage all favour their informed structural assessment for continued use. The authors write in their paper (Moy et al., 2009) that 'there has been no recent research' into the mechanical properties of wrought iron, but - taking a rather elastic view of what constitutes 'recent' - I refer to a 1999 study by Morgan (Morgan, 1999), a paper by Morgan and Hooper (1992), looking at the properties of wrought iron from the $S S$ Great Britain, and a paper by Cullimore (1967) reporting on strength and fatigue tests on wrought iron from the recently dismantled Chepstow railway bridge designed by I.K. Brunel.

I would respectfully question some of the authors' observations on the manufacture and historical application of wrought iron. In (2) they comment that 'wrought iron wholly replaced cast iron for railway bridge construction' following the 1847 collapse of the Dee Bridge. In practice, cast iron continued in use for railway arch bridges for some time after this; a notable late example was the $46 \mathrm{~m}$ span Carron Bridge of 1863 over the River Spey in Scotland, designed by Alexander Gibb. In (3) they suggest that in making wrought iron the molten pig iron, after being stirred or 'puddled' to expose it to atmospheric oxygen, which largely removed carbon and other impurities 'was then cooled until it became a semi-molten, pasty, iron and slag mixture'. It was the loss of carbon that raised the melting point of the remaining melt such that without losing temperature it became semi-molten and spongy, after which it was removed from the furnace in balls of approximately $50 \mathrm{~kg}$ each and initially hammered into 'blooms', typically somewhat larger than the $25 \mathrm{~mm}$ square bars implied in the paper.

Making wrought iron from pig iron was always a batch process carried out by hand - in effect a craft-based industry - and it was this, combined with the amount of subsequent working, that resulted in the chemical and physical variability of the product. This is reflected in its variable engineering properties, a fact that appears from contemporary writing to have been well understood by both the iron-makers and the engineers who specified and used wrought iron.

The manufacture and properties of wrought iron have been reviewed in Chapter 5 of a valuable recent Historic Scotland publication by Swailes (2006), who is leading further studies of wrought iron at Manchester University, the publication of which is awaited with interest. Two books by the late W.K.V. Gale $(1967 ; 1969)$ include vivid accounts by someone who was intimately acquainted with the making of wrought iron (and cast iron and steel).

I was surprised at the quoted values for $k$, the multiplier on standard deviation to relate mean and characteristic values of strength. The multiplier for an infinite number of samples is given as 1.64, which I agree, but the multipliers for finite numbers are consistently higher than those adopted in the Steel Construction Institute guide (paper reference 2, Table 7.2), which referenced as source the values given in the then draft Eurocode 1.

In any case, given the variability of the material, I am puzzled that the authors encourage - if only by implication - the testing of a large number of specimens if structure-specific testing is required' in their Conclusion 11(c). Their own test results show that even in a single girder there is a wide variation in properties. Removal and testing of specimens is usually costly, time consuming and disruptive (and may not be acceptable in the case of a historic structure, or critical structural elements such as tie-rods). Moreover, such testing is unlikely to inform the engineer better than would be achieved by adopting the characteristic yield strength of $220 \mathrm{~N} / \mathrm{mm}^{2}$ and a partial material factor of 1.2 advised in the well-known bridge assessment guide $B D 21$, which I was surprised not to see cited in the paper (The Highways Agency, 2001). These values were also adopted when I was writing the SCI appraisal guide (paper reference 2 - please note that this appeared in 1997, not 1975). 
I was surprised too that the authors recommend in Conclusion 11(d) that for wrought iron 'all design [presumably also appraisal, before considering possible strengthening] should be based on elastic behaviour'. Those who made and specified structural wrought iron in the 19th century understood its anisotropic properties: it was strongest and tougher in the direction of rolling, parallel to the alignment of the slag fibres. So, when the stress in use was mainly longitudinal, such as in tierods, bolts and chains, the sheared bars would be laid with their axes parallel before further hot-rolling, which forge-welded them together. This would maximise the ductility in the direction of stressing. Likewise, for a boiler, for example, in which stresses were biaxial, the bars would be piled with alternate layers oriented at right angles so that ductility was again available in both stressed directions. Riveting - the commonest method of joining wrought iron elements structurally - was dependent on the malleability of the hammered hot rivet to fill its individual hole, while the performance of rivet groups in wrought iron, as in steel, necessarily involved a degree of plasticity.

I apologise for responding at some length to this paper; but, given the relative infrequency now of writings on wrought iron, no longer made but still widely present in structures, I hope that my comments are of interest. I look forward to the authors' reply.

One last comment is addressed to the editors of Proceedings. This paper was only quite recently drawn to my attention by a colleague. I, like I am sure many others, do not subscribe to what are now the numerous journals that collectively form the Institution's Proceedings. I would have thought that the target audience for this paper would be engineers involved in work on existing (often historic) structures, and as such I regret that it was not published in the newly launched Engineering History and Heritage journal, where it could well have attracted a wider readership.

\section{Authors' reply}

The authors thank Mr Bussell for his discussion of their paper; it is rewarding to know that the paper has been considered in such detail.

Our intention was not to score points but merely to point out that we had been able to undertake a carefully planned and executed piece of research. Mr Bussell has mentioned other work and we have reported in Table 6 some of the results, including SS Great Britain (four tensile specimens) and Chepstow (nine tensile specimens). In our research we tested 99 tensile specimens.

In our historical review we stated that wrought iron replaced cast iron for tension members in railway structures and that was correct. We apologise for our slightly misleading sentence concerning total replacement. There is a wide literature about the production of wrought iron and we presented a distillation that we felt described the process in general terms.

We completely concur with Mr Bussell's third paragraph; indeed we comment in the paper that wrought iron production was one of the great Victorian industries, with hundreds of companies involved. The results presented in Figure 18 and Table 6 confirm his point about variability.

We thank Mr Bussell for the information about the three publications and we look forward to the results from the Manchester work. Actually, many of the publications mentioned by Mr Bussell are referenced in (6) in our paper.

We used BS2846-3 as our source for the multipliers; they are higher than those in the SCI guide. We felt that the statistics in the British Standard were better. The British Standard is referenced in the paper but we missed that two references had been rolled together. The correct reference is given at the end of our response (BSI, 1975).

We were actually doing the opposite of what $\mathrm{Mr}$ Bussell suggests. Precisely because the preparation of samples is costly, time consuming and disruptive we were discouraging structurespecific testing by emphasising the large number of specimens that would be required. However, an assessor could still consider such testing but needs to be aware of what would be required.

Our suggestions about design (of remedial schemes) are not incompatible with Mr Bussell's argument. In the early days of steel design, for example, an elastic approach was used but the ductility of the steel (plasticity) was inherent in the design of bolted or riveted connections. We were also concerned with the delamination of wrought iron in compression as reported in the paper. We assume that Mr Bussell is not arguing for plastic design of wrought iron remedial schemes. It is worth adding that the research reported in the paper was part of a wider project looking at the suitability of carbon fibre reinforced polymer composite for strengthening or stiffening wrought iron structures. A companion paper (in which Mr Bussell's own paper is correctly dated) is referenced at the end (Moy and Clarke, 2009).

The results reported in Tables 2 and 3 bear out the points made by $\mathrm{Mr}$ Bussell concerning directional properties. The flange plates had markedly different elongations in the with-grain and cross-grain directions, whereas the web plate had similar elongations in the two directions (it is not appropriate to use with and cross-grain for the web).

An apology is not needed. Wrought iron is a fascinating and most unusual structural material and is still an important part 
of the infrastructure of the UK. Mr Bussell's detailed discussion merited a similar response.

\section{REFERENCES}

BSI (1975) BS2846: Part 3 1975. Guide to statistical interpretation of data - Part 3: Determination of a statistical tolerance interval. BSI, London, UK.

Cullimore MSG (1967) The fatigue strength of wrought iron after weathering in service. The Structural Engineer 45(5): 193-199.

Gale WKV (1967) The British Iron and Steel Industry. David and Charles, Newton Abbot, UK.

Gale WKV (1969) Iron and Steel. Longmans, London, UK. Morgan J (1999) The strength of Victorian wrought iron.

Proceedings of the Institution of Civil Engineers - Structures and Buildings 134(4): 295-300.
Morgan JE and Hooper RM (1992) SS Great Britain - the wrought iron ship. Metals and Materials 8: 655-659.

Moy SSJ and Clarke HWJ (2009) Strengthening wrought iron structures using CFRP. Proceedings of the Institution of Civil Engineers - Structures and Buildings 162(SB4): 251-261.

Moy SSJ, Clarke HWJ and Bright SR (2009) The engineering properties of Victorian structural wrought iron.

Proceedings of the Institution of Civil Engineers Construction Materials 162(1): 1-10.

Swailes T (2006) Guide for Practitioners 5: Scottish Iron Structures. Historic Scotland, Edinburgh, UK.

The Highways Agency (2001) Design Manual for Roads and Bridges, Volume 3 Highway Structures: Inspection and Maintenance, Section 4: Assessment, Part 3: BD21/01 The Assessment of Highway Bridges and Structures. The Stationery Office, London, UK.

\section{WHAT DO YOU THINK?}

To discuss this paper, please email up to 500 words to the editor at journals@ice.org.uk. Your contribution will be forwarded to the author(s) for a reply and, if considered appropriate by the editorial panel, will be published as discussion in a future issue of the journal.

Proceedings journals rely entirely on contributions sent in by civil engineering professionals, academics and students. Papers should be 2000-5000 words long (briefing papers should be 1000-2000 words long), with adequate illustrations and references. You can submit your paper online via www.icevirtuallibrary.com/content/journals, where you will also find detailed author guidelines. 